\title{
Teaching NeuroImages: Hutchinson Sign in Herpes Zoster Ophthalmicus
}

Eiichiro Amano, MD, and Akira Machida, MD, PhD

Neurology ${ }^{\circledR}$ 2021;96:e2033-e2034. doi:10.1212/WNL.0000000000011285

Figure 1 Hutchinson Sign in Herpes Zoster Ophthalmicus
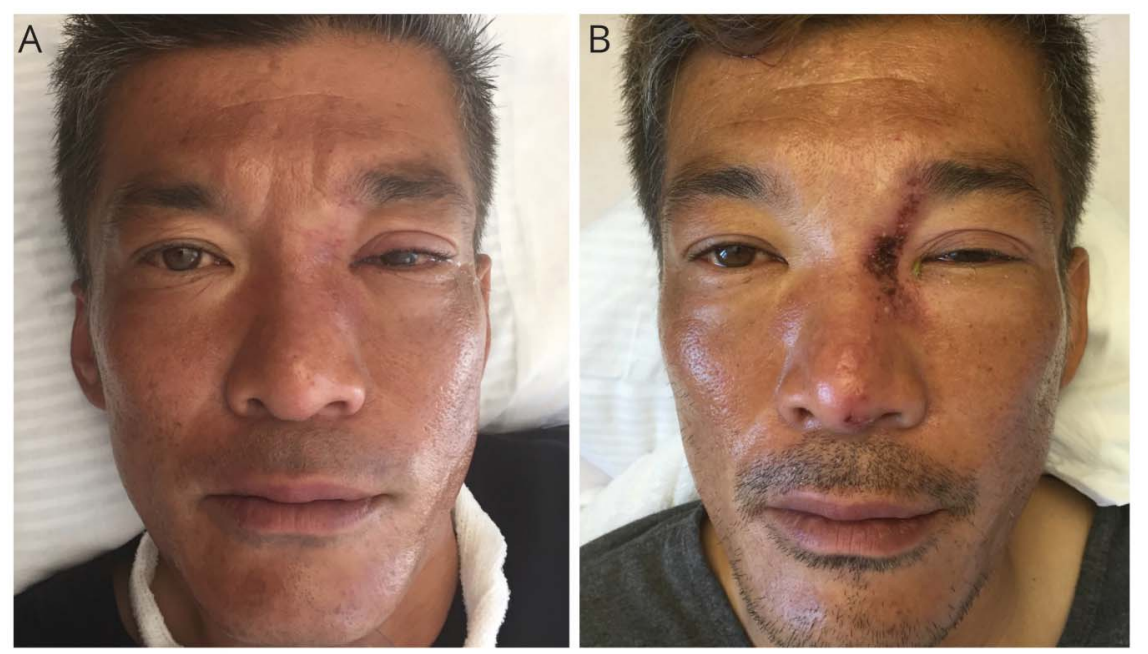

Lacrimation and conjunctival injection in the left eye with periorbital edema were evident on day 7 (A). On day 10 , zoster appeared in the root, dorsum, and apex of the nose, which is known as Hutchinson sign (B).

A 42-year-old immunocompetent man developed left-sided orbital and temporal stabbing pain, accompanied by ipsilateral lacrimation and conjunctival injection with periorbital edema (figure 1A). On day 10, Hutchinson sign, which is defined as zoster skin lesions in the root, dorsum, and apex of the nose, ${ }^{1}$ became evident with severe keratoconjunctivitis and iritis (figure 1B). PCR testing of blood revealed varicella-zoster virus and he was diagnosed with herpes zoster ophthalmicus (HZO). Hutchinson sign indicates the involvement of the nasociliary nerve, a branch of ophthalmic nerve innervating the eyelid, nose, and eye (figure 2), and is the strong predictor of the ocular complications of HZO. ${ }^{1,2}$ Compared to HZO in the absence of Hutchinson sign, the presence of Hutchinson sign indicates a 3.4-fold increase in the risk of developing ocular inflammation and a 4 -fold increase in the risk of developing corneal denervation. $^{2}$

\section{Study Funding}

This research did not receive any specific grant from funding agencies in the public, commercial, or not-for-profit sectors.

\section{Disclosure}

The authors report no disclosures relevant to the manuscript. Go to Neurology.org/ $\mathrm{N}$ for full disclosures.

\section{Correspondence}

Dr. Amano

amanuro@tmd.ac.jp

\section{MORE ONLINE}

$\rightarrow$ Teaching slides

links.lww.com/WNL/

B295 
Figure 2 Distribution of the Nasociliary Nerve

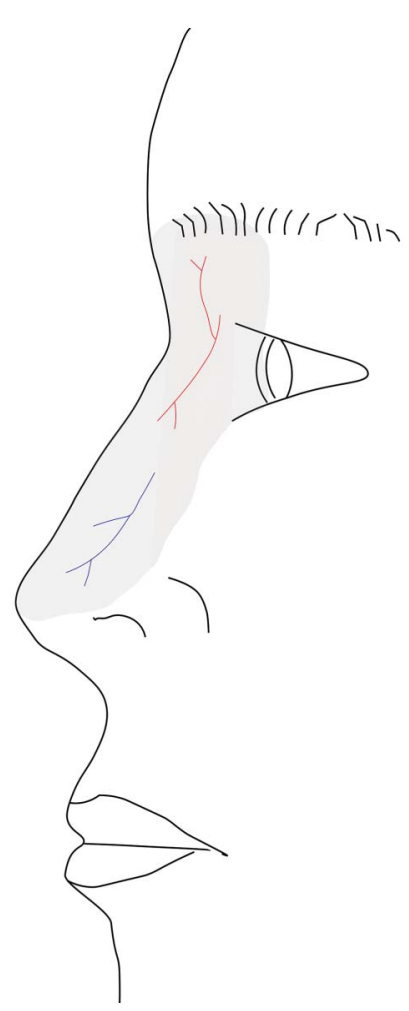

The dermatome of the nasociliary nerve is shown with the infratrochlear (red) and the external nasal (blue) nerve branches.

\section{Appendix Authors}

\begin{tabular}{lll}
\hline Name & Location & Contribution \\
\hline $\begin{array}{l}\text { Eiichiro } \\
\text { Amano, MD }\end{array}$ & $\begin{array}{l}\text { Tsuchiura Kyodo } \\
\text { General Hospital }\end{array}$ & $\begin{array}{l}\text { Designed and analyzed the data, } \\
\text { major role in the acquisition of data }\end{array}$ \\
\hline $\begin{array}{l}\text { Akira } \\
\text { Machida, } \\
\text { MD, PhD }\end{array}$ & $\begin{array}{l}\text { Tsuchiura Kyodo } \\
\text { General Hospital }\end{array}$ & Interpreted the data \\
\hline
\end{tabular}

\section{References}

1. Liesegang TJ. Herpes zoster ophthalmicus natural history, risk factors, clinical presentation, and morbidity. Ophthalmology 2008;115:S3-S12.

2. Zaal MJW, Volker-Dieben HJ, D'Amaro J. Prognostic value of Hutchinson's sign in acute herpes zoster ophthalmicus. Graefes Arch Clin Exp Ophthalmol 2003;241: 187-191. 


\section{Neurology}

\section{Teaching NeuroImages: Hutchinson Sign in Herpes Zoster Ophthalmicus}

Eiichiro Amano and Akira Machida

Neurology 2021;96;e2033-e2034 Published Online before print December 2, 2020

DOI 10.1212/WNL.0000000000011285

This information is current as of December 2, 2020

Updated Information \&

Services

References

Subspecialty Collections

Permissions \& Licensing

Reprints including high resolution figures, can be found at:

http://n.neurology.org/content/96/15/e2033.full

This article cites 2 articles, 0 of which you can access for free at: http://n.neurology.org/content/96/15/e2033.full\#ref-list-1

This article, along with others on similar topics, appears in the following collection(s):

All Neuro-ophthalmology

http://n.neurology.org/cgi/collection/all_neuroophthalmology

Clinical neurology examination

http://n.neurology.org/cgi/collection/clinical_neurology_examination

Neuropathic pain

http://n.neurology.org/cgi/collection/neuropathic_pain

Viral infections

http://n.neurology.org/cgi/collection/viral_infections

Information about reproducing this article in parts (figures,tables) or in its entirety can be found online at:

http://www.neurology.org/about/about_the_journal\#permissions

Information about ordering reprints can be found online:

http://n.neurology.org/subscribers/advertise

Neurology ${ }^{\circledR}$ is the official journal of the American Academy of Neurology. Published continuously since 1951 , it is now a weekly with 48 issues per year. Copyright @ 2020 American Academy of Neurology. All rights reserved. Print ISSN: 0028-3878. Online ISSN: 1526-632X.

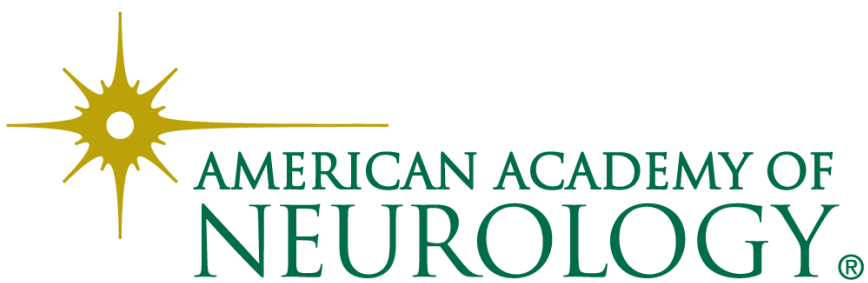

